\title{
Radioimmunoassay of Plasma Cortisol
}

\author{
Takuo MAKINO and Akira KAMBEGAWA \\ Pharmacological Research Department, Teikoku Hormone, Mfg., Co. Ltd. \\ Shimosakunobe, Kawasaki, Japan
}

A radioimmunoassay for the determination of plasma cortisol is described. The antiserum against cortisol was produced by the immunization of rabbits with cortisol21-BSA synthesized from cortisol via hemisuccinate derivative. The antiserum obtained had high affinity and high specificity for cortisol. $0.002 \mathrm{ml}$ of plasma diluted with water was used for the assay. After 1,000 dpm of tritiated cortisol was added to compensate for procedual losses, the sample was extracted with ether. The dried extract was applied to microcolumn of Sephadex LH-20 and eluted with benzene-methanol (85:15). A 1/2 aliquot of the eluate was used for measuring recovery of the added tracer, and what remained added with $10,000 \mathrm{dpm}$ of the tritiated cortisol was incubated with the antiserum in a dilution of the borate buffer $(\mathrm{pH}$ 8.0) containing $0.06 \% \mathrm{BSA}$ and $0.05 \%$ bovine gamma globulin. The free and bound steroids were separated by $50 \%\left(\mathrm{NH}_{4}\right)_{2} \mathrm{SO}_{4}$, and tritium activity in the supernatant was counted. The results determined by this method were satisfactory. Furthermore, we investigated both the No Chromatographic method and the Direct method in which plasma was directly incubated with the antiserum without extraction. These simplified methods were in good correlation with the Chromatographic method in the normal subjects.

(See pp. 1297〜1305) 


\title{
Radioimmunoassay による血中 Cortisol の測定
}

\author{
帝国藏器製薬薬理研究部 \\ 牧野拓 雄, 神戸川明
}

（昭和48年 7 月 17 日受付）

Cortisol-21-hemisuccinate-BSA を合成して家鬼に免疫し，cortisol に対する抗血清を作製後，てれを 用いて radioimmunoassay (RIA) による血漿中 cortisol の測定法について検討した。血漿 cortisol はエーテル抽出後 Sephadex LH-20 カラムクロマトにより純化して RIA を行ない満足すべき成績を 得たが，クロマトを省略した方法，さらには抽出も省略して抗血清と反応させる方法を健康人の血漿を 用いて検討した結果では，いずれも簡易測定法としての有用性が示唆された。

\section{I 緒言}

従来, 血中 corticoid の測定には cortisol や corticosterone 等の 11-OHCS を硫酸螢光法によつて測定 する方法が一般的であるが， cortisol そのものを定量するためには double isotope derivative method の

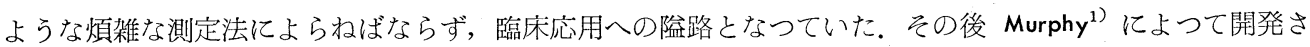
れた competitive protein binding assay (CPBA) により比較的容易に測定が可能となつたが, cortisol と 結合する corticosteroid binding globulin (CBG) の特異性などに問題点が残されていた。

一方, Abraham $^{2)}$ によつて発表された estradiol-17 $\beta$ の RIA は1970年代に入ると他のステロイドホルモ ンの分野にも応用され，特異性に優れた，高力価の抗血清の作成により血中ステロ.イドの微量測定はめざま しい進歩をとげつつあるが， cortisol の RIA については，いまだその報告も極めて少ない。

今回われわれは cortisol に対する抗血清を作製，RIA による血中 cortisol の測定およびその簡易化につ いての考察を行なつたので報告する。

\section{II 実 験 材 料}

\section{a 試薬・装置}

1) Cortisol-1, $2-{ }^{3} \mathrm{H}(45 \mathrm{Ci} / \mathrm{mM})$ : The Radiochemical Center. 随時 Sephadex LH-20 (benzene : methanol $=85:$ 15) にて精製を行なう.

2) bovine serum albumin crystalline (BSA) fraction V, complete Freund's adjuvant, bovine gamma globulin fraction II, dioxane scintillator は既報3゙にしたがう。 その他の試薬はすべて特級を使用す る.

3）抗血清稀橎液 : 0.05M borate buffer ( $\mathrm{pH}$ 8.0) 飞 BSA を 0.06\%, bovine gamma globulin を 0.05 \%の割合で溶解したもの.

4) クロマトカラム : Sephadex LH-20 (Pharmacia Fine Chemicals) を benzene : methanol (85:15) の溶媒で 1 晚膨じゆんさせ, 減圧して空気泡を除き, 径 $7 \mathrm{~mm}$ のカラムにその $2 \mathrm{ml}$ をつめ, 新しく調整し

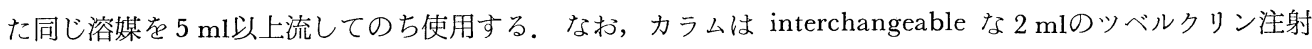
筒にて代用出来る.

5）液体シンチレーションカウンター：Aloka LSC-651

\section{b 抗原の合成}


cortisol $1.2 \mathrm{~g}$ と succinc anhydride $1.2 \mathrm{~g}$ を pyridine $16 \mathrm{ml}$ に溶汃して一晚放置後, 水 $20 \mathrm{ml}$ を冷やし ながら加え，次いで 4N-HCl を滴下して生じた沈でんをとり acetone にて再結晶を行なつて cortisol-21hemisuccinate $1.18 \mathrm{~g}$ を得る (同定：NMR, IR, m.p.).てれを Erlanger ら ${ }^{4) 5}$ の方法にしたがつて BSA を結合させ cortisol-21-hemisuccinate-BSA $2.2 \mathrm{~g}$ を得た。

\section{c 抗血清の作製}

抗原 $1 \mathrm{mg}$ 亿注射用生理食塩水 $0.5 \mathrm{ml}$ および complete Freund's adjuvant $0.5 \mathrm{ml}$ を加えてエマルショョ ンとし， 5 羽の成熟家鬼 (Newzeeland White 種, 雄, 約 $2.5 \mathrm{~kg}$ ) の背部皮下 4 ケ所以上に分けて最初の 1 ケ月は 2 回，以後は月 1 回の間隔で注射を行なつた。採血は注射後10日目に耳静脈より行ない，血清を分離 して deep freezer にて保存した. cortisol に対する抗体の産生はすべての家鬼において認められ，最も力 価の上昇した一羽については投与 3 ケ月で20,000倍，4 ケ月で40,000倍まで抗血清の稀釈が可能であつたが， 以後11ケ月まで力価の変動はみられなかつた。 なお，Abraham らの方法 ${ }^{6)}$ とり求めた本抗血清の association constant $(\mathrm{K})$ は $1.06 \times 10^{9} \mathrm{l} / \mathrm{mole}$ であつた.

\section{III 測 定 方 法}

\section{1）抽出・精製}

回収率を補正するための cortisol- ${ }^{3} \mathrm{H}$ 1,000dpm を添加してあるスピッツ遠沈管に被検血漿を入れる。血 漿量は通常 $0.002 \mathrm{ml}$ を用い, 水で稀哷して $0.2 \mathrm{ml}$ とする. (血漿 $0.1 \mathrm{ml}$ に水を加えて $10 \mathrm{ml}$ とし, その $0.2 \mathrm{ml}$ を用いる).乙れに 5 倍量のエーテルを加えて振洫後, 下圈を捨て, 水 $0.2 \mathrm{ml}$ を加えて振り, 上清 を他の試験管にとり，窒素ガススプレーにて 乾固する．てれを Sephadex LH-20 のクロマトカラムに benzene : methanol $(85: 15)$ の溶媒 $0.1 \mathrm{ml}$ で添加し, さらに $0.1 \mathrm{ml}$ で試験管を洗つてカラムに加えて のち, 同じ溶媒を流して cortisol fraction を採取する。

Fig. 1. Elution pattern of steroids by the microcolumn chromatography.

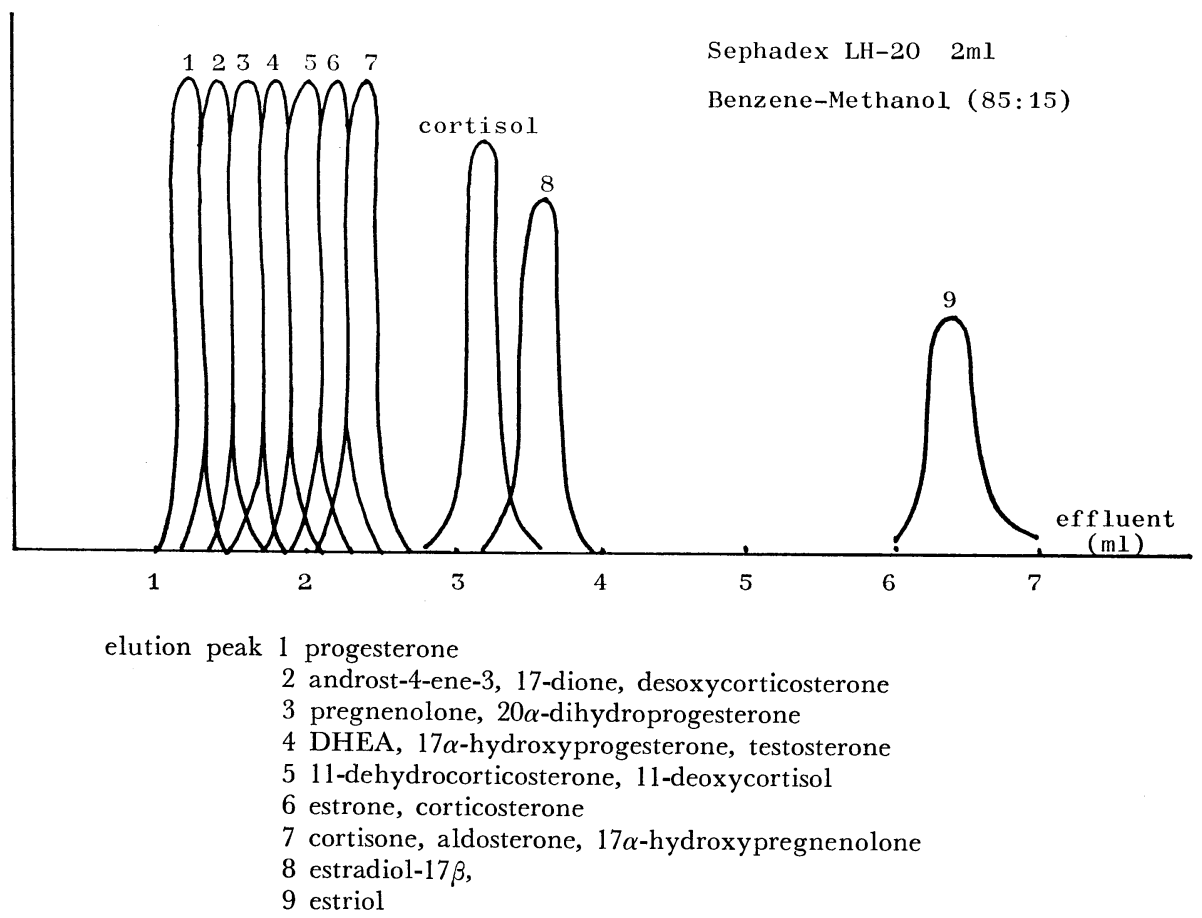


このクロマト法による主なステロイドの elution pattern は Fig. 1 に示すでとくで, cortisol は他の corticoid と分離が可能であり, かつ, 再現性はきわめて良好で, 通常, 吸着後 $2.4 \mathrm{ml}$ により prewash を 行ない，さらに $1.4 \mathrm{ml}$ を溶出させて cortisol fraction として採取する. 採取液の $1 / 2$ 量は ${ }^{3} \mathrm{H}$ 量を測定し て最初に加えたものとの比から回収率を求め, 残りについて RIA を行なう。

\section{2 ) RIA}

標準曲線作製用としてスピッツに加えた cortisol の純品 0〜500pg とクロマトにより採取した RIA fraction とに cortisol- ${ }^{3} \mathrm{H}$ 10,000dpm を加えて乾固し，稀 釈抗血清 $0.25 \mathrm{ml}$ を加え 30 分放置後， 50\% $\left(\mathrm{NH}_{4}\right)_{2} \mathrm{SO}_{4} \quad 0.25 \mathrm{ml}$ を加えて混和し 10 分後に 3,000 rpm にて10分間遠沈を行なうが，以上の操作はすべて 室温において可能である. ついで上清 $0.2 \mathrm{ml}$ を counting vial に入れ dioxane scintillator $12 \mathrm{ml}$ を加え て放射能(P)を測定し，下の(1)式から cortisol- ${ }^{3} \mathrm{H}$ の結合率(B)を求める. 同時に作製した標準曲線を用いて検 体の結合率からステロイド量(M)を求め，(2)式により血漿中 cortisol 濃度(S)を算出する.

$$
\begin{aligned}
& \mathrm{B}(\%)=\left(\mathrm{A}-\mathrm{P} \times \frac{0.5}{0.2}\right) \times \frac{100}{\mathrm{~A}} \\
& \mathrm{~S}(\mathrm{ng} / \mathrm{ml})=(\mathrm{M}-\mathrm{a}) \times \frac{100}{\text { 回収率 }(\%)} \times \frac{2 \times 10^{3}}{\mathrm{~V}} \\
& \mathrm{~A}: \text { assay に用いた }{ }^{3} \mathrm{H} \mathrm{dpm} \\
& \mathrm{a}: \text { water blank 值（水を用いて検体と同様操作を行なって求めた值） } \\
& \mathrm{V}: \text { 被検血漿量 }
\end{aligned}
$$

\section{IV 実 験 成 績}

\section{1) 標準曲線}

本実験に用いた 40,000 倍稀釈の 抗血清により作製した標準曲線は Fig. 2 に示すでとくで $0 \mathrm{pg}$ にける 結合率は 89.6 $0.47 \%$ (mean \pm S.D. 以下同様), $500 \mathrm{pg}$ においては $12.1 \pm 2.23 \%$ で, 横軸のステロイド量 を対数目盛で表わすと 0 ～ $500 \mathrm{pg}$ の範囲内においてはほぼ直線に近いものが得られた。 また，95\%信頼限界 において $0 \mathrm{pg}$ と区別し得る最小ステロイド量は $5 \mathrm{pg}$ であることから，ての標準曲線から求められる感度 (sensitivity) は 5pg であるといえる。

\section{2）精度および再現性}

既知量の cortisol を血漿および水に加えて全測定操作を行ない回収率を補正して測定値を求め, 本測定 法の accuracy を検討した結果は, Table 1 に示すごとくほぼ満足すべきものであつた.

また，被検血漿を duplicate に測定して求めた precision は within (intra-) assay variance が 13.7\% (range $14.0 \sim 128 \mathrm{ng} / \mathrm{ml}, \mathrm{N}=22$ ), between (inter-) assay variance $か: 17.8 \%$ (range 7.8 99.0ng/ml, N =7) であった.

2 例の男子血漿を各 5 回反復測定して求めた本測定法の再現性（reproducibility）は $47.3 \pm 7.92 \mathrm{ng} / \mathrm{ml}$ C.V. (coefficient of variation) 16.6\% および $65.1 \pm 12.4 \mathrm{ng} / \mathrm{ml}$, C.V. 19.1\% であつた.

\section{3）回収率および水盲検值}

被検血漿に加えた cortisol- ${ }^{3} \mathrm{H}$ の全測定操作を通じての回収率は $65.8 \pm 6.11 \%(\mathrm{~N}=55)$ であつた. また，本測定法の water blank 值は $6.97 \pm 3.93 \mathrm{pg} / \mathrm{sample}(\mathrm{N}=22)$ であつた.

\section{4) Specificity}

本抗血清の各種ステロイドに対する交叉反応の検定は cortisol- ${ }^{3} \mathrm{H}$ とそれぞれのステロイドを用いて反応 曲線を作製し，50\%結合率を示す cortisol 量とそれぞれのステロイド量との比により％ cross reaction を 求めた. との結果は Table 2 に示すでとくで, cortisol の本抗血清に対する affinity を100とすると $17 \alpha-$ hydroxyprogesterone か392.3と大きく交叉したが cortisone の28.1を除いては他の主な corticoid は 2 亿 程度で androgen, estrogen はいずれも1 以下であつた。 なお合成 corticoid の prednisolone は 10.9\%の 
Fig. 2. Standard curve for cortisol (each point represents the mean of 5 determinations \pm S.D.)

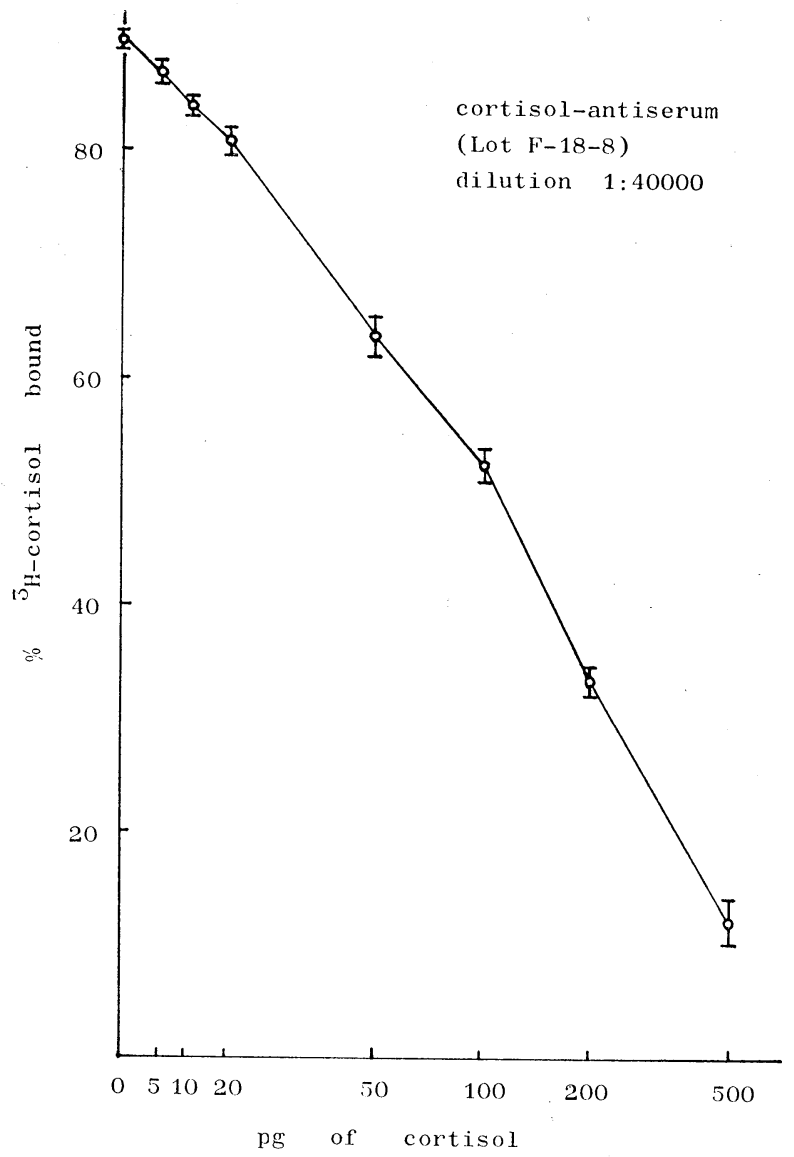

Table 1. Accuracy of the Ghromatographic method.

\begin{tabular}{|c|c|c|c|c|c|c|}
\hline \multirow[b]{2}{*}{ sample } & \multirow{2}{*}{$\begin{array}{c}\text { steroid } \\
\text { added } \\
(\mathrm{pg})\end{array}$} & \multicolumn{4}{|c|}{ steroid quantified } & \multirow[b]{2}{*}{ regression equation } \\
\hline & & $\begin{array}{c}\text { mean } \\
(\mathrm{pg})\end{array}$ & $\begin{array}{l}\text { standard } \\
\text { deviation }\end{array}$ & $\begin{array}{l}\text { standard } \\
\text { error }\end{array}$ & $\begin{array}{c}\text { coefficient } \\
\text { of variation } \\
(\%)\end{array}$ & \\
\hline \multirow{6}{*}{$\begin{array}{l}\text { water } \\
0.1 \mathrm{ml}\end{array}$} & 0 & 3.75 & 2.98 & 1.49 & 79.4 & \multirow{6}{*}{$Y=0.990 X+3.45$} \\
\hline & 20 & 24.2 & 4.34 & 2.17 & 17.9 & \\
\hline & 50 & 60.7 & 12.0 & 6.01 & 19.7 & \\
\hline & 100 & 99.0 & 18.2 & 9.14 & 18.3 & \\
\hline & 200 & 192 & 20.0 & 10.0 & 10.4 & \\
\hline & 500 & 502 & 16.7 & 8.30 & 3.32 & \\
\hline \multirow{6}{*}{$\begin{array}{c}\text { male } \\
\text { plasma } \\
0.002 \mathrm{ml}\end{array}$} & 0 & 42.7 & 10.9 & 5.47 & 25.5 & \multirow{6}{*}{$Y=0.884 X+45.8$} \\
\hline & 20 & 61.7 & 9.59 & 4.79 & 15.5 & \\
\hline & 50 & 98.0 & 10.5 & 5.27 & 10.7 & \\
\hline & 100 & 136 & 21.6 & 10.8 & 15.8 & \\
\hline & 200 & 217 & 27.3 & 13.6 & 12.5 & \\
\hline & 500 & 489 & 27.7 & 13.8 & 5.66 & \\
\hline
\end{tabular}


Table 2. Cross reaction with the antiserum against cortisol-21-BSA (dilution 1 :40000)

\begin{tabular}{l|c}
\hline \multicolumn{1}{c|}{ compounds } & $\begin{array}{c}\% \text { cross } \\
\text { reaction }\end{array}$ \\
\hline cortisol & 100 \\
17 $\alpha$-hydroxyprogesterone & 92.3 \\
cortisone & 28.1 \\
11-desoxycortisol & 4.55 \\
20 $\alpha$-dihydroprogesterone & 3.82 \\
aldosterone & 2.88 \\
corticosterone & 2.87 \\
11-desoxycorticosterone & 2.64 \\
progesterone & 2.42 \\
11-dehydrocorticosterone & 0.92 \\
$5 \alpha$-pregnanedione & 0.10 \\
tetrahydrocortisol & 0.08 \\
pregnenolone & $<0.04$ \\
$5 \beta$-pregnanediol & $<0.04$ \\
pregnanetriol & $<0.04$ \\
cholesterol & $<0.04$ \\
testosterone & 1.00 \\
dehydroepiandrosterone & 0.21 \\
androst-4-ene-3, 17-dione & 0.08 \\
$5 \alpha$-dihydrotestosterone & $<0.04$ \\
androsterone & $<0.04$ \\
estrone & 1.17 \\
estradiol-17 $\beta$ & 0.40 \\
estriol & 1.25 \\
chlormadinone acetate & $<0.08$ \\
prednisolone & 10.9 \\
triamcinolone & $<0.20$ \\
\hline & \\
\hline
\end{tabular}

\section{交叉率を示した。}

\section{5）本測定法と螢光法との比較}

血中の cortisol, corticosterone 等の 11-hydroxycorticosteroids (11-OHCS) を測定する螢光法 ${ }^{7)}$ と 本測定法との相関関係は同一血漿の両者による測定 值 $(\mathrm{n}=18)$ により比較して検討した. ての結果,

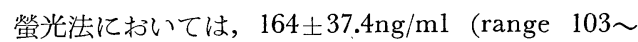
$230 \mathrm{ng} / \mathrm{ml})$, 本測定法に求いては $75.6 \pm 25.1 \mathrm{ng} / \mathrm{ml}$ (range 38.9〜 137ng/ml) であり， 螢光法は本測定 法の約 2 倍の高值を示した.

\section{6) 測定値}

本法による末梢血中 cortisol 值（採血時間不定） は正常成人男子 $63.5 \pm 21.9 \mathrm{ng} / \mathrm{ml} \quad(\mathrm{n}=31)$, 正常成 人女子 $95.5 \pm 32.7 \mathrm{ng} / \mathrm{ml}(\mathrm{n}=14)$, 妊娠 40 週の婦人 $259 \pm 87.4 \mathrm{ng} / \mathrm{ml} \quad(\mathrm{n}=4)$, 健康人 3 例の朝加ら夕方 までの日内変動は Fig. 3 に示すでとくである.

\section{$\mathrm{V}$ 簡易測定法の検討}

\section{1) No Chromato 法}

既述の Chromato 法からクロマトによる cortisol の純化，精製を省略した測定法について検討した。 すなわち，被検血漿のエーテル抽出物を乾固しての ち，ただちにメタノール $0.4 \mathrm{ml}$ を加え $0.2 \mathrm{ml}$ は回 収率補正のための counting に供し，残りの $0.2 \mathrm{ml}$ について assay を行なう. 本法の精度は良好であり， さらに within assay variance $16.3 \% \quad(n=31)$, between assay variance 19.3\% $(n=10)$, 回収率 $76.0 \pm 4.48 \% \quad(\mathrm{n}=70)$. water blank $3.8 \pm 4.4 \mathrm{pg} /$

Fig. 3. Diurnal variation of plasma cortisol.

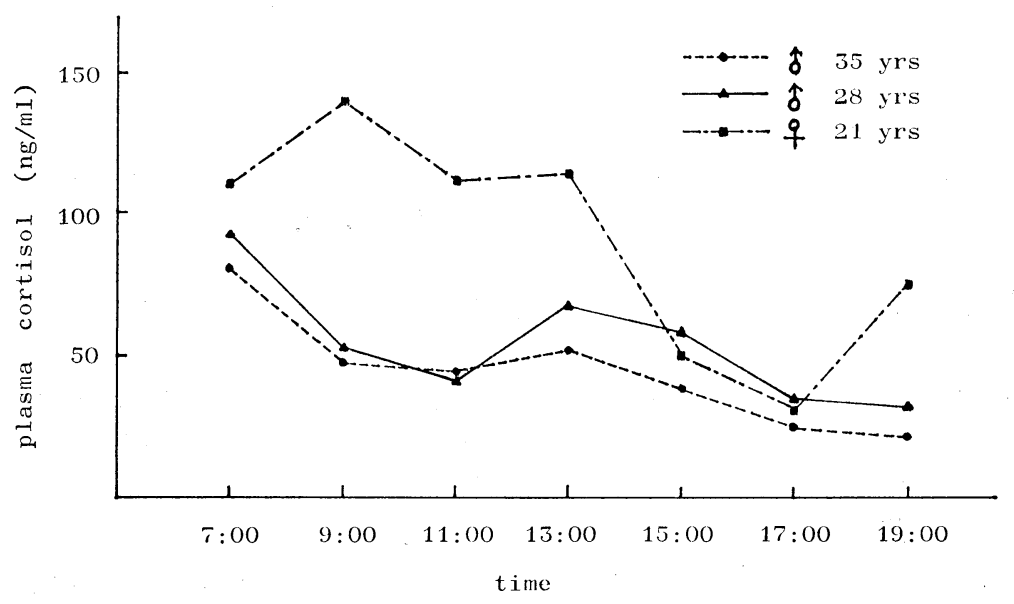


sample であつた. 本法と Chromato 法との相関関係は正常男子および正常女子の血漿（N=20）について 両者の測定法によりその測定値を比較した。 ての結果, Chromato 法 $(\mathrm{x})$ による測定值は $64.9 \pm 25.5 \mathrm{ng} / \mathrm{ml}$, No Chromato 法(y)によるそれは $79.5 \pm 40.2 \mathrm{ng} / \mathrm{ml}$ で，両者間には Fig. 4 亿示すでとく良好な相関関係が

Fig. 4. Comparison of plasma cortisol values between with and without chromatography.

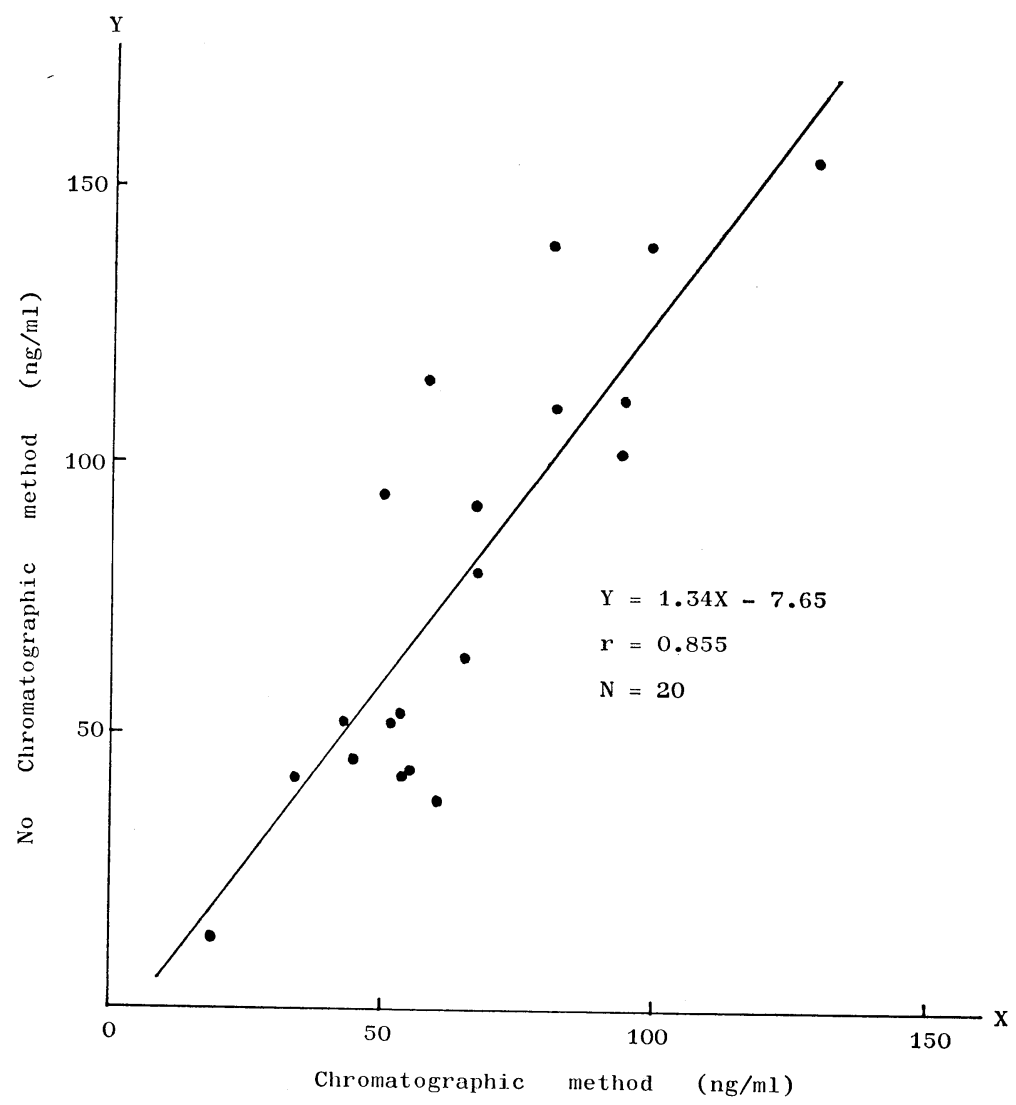

認められるものの, $\mathrm{y}$ と $\mathrm{x}$ との差の $\mathrm{x}$ 亿対する割合 $\left(\frac{\mathrm{y}-\mathrm{x}}{\mathrm{x}} \times 100\right)$ は $19.5 \pm 36.5 \%$ であり, てれの平 均值の $95 \%$ 信頼限界における範囲は 36.6 2.38\% であつた。 また，対応する 2 群の平均値の比較（paired comparison 法)では $\mathrm{y}$ は $\mathrm{x}$ 亿対し有意の差が認められた（ $\mathrm{p}<0.05 ）$.

\section{2) Direct 法}

吉見ら ${ }^{8)}$ の報告にほぼ準拠して被検血漿からの有機溶媒抽出を省略して抗血清と反応させ測定する方法に ついて検討した.

すなわち，水で10倍に稀釈した被検血漿 $0.01 \mathrm{ml}$ （血漿として0.001 ml）をマイクロシリンジで採取し，乙 れに cortisol- ${ }^{3} \mathrm{H}$ 10,000dpm を含むメタノール $0.01 \mathrm{ml}$ を加えて混和し，稀釈抗血清 $0.49 \mathrm{ml}$ を加えて 30 分間室温放置後, $50 \%\left(\mathrm{NH}_{4}\right)_{2} \mathrm{SO}_{4} 0.49 \mathrm{ml}$ を加え 10 分放置, 遠沈して上清 $0.4 \mathrm{ml}$ をとり, dioxane scintillator により放射能を測定，(1) 式によつて結合率を求める. 同時に水 $0.01 \mathrm{ml}$ を用いて検体と同様に操作 して求めた標準曲線により被検血漿中の cortisol 濃度を求めるが，本法においては回収率の補正を行なう 
必要はない．なお，本法における抗血清の稀釈倍数は高く，他の方法においては40,000倍稀釈の抗血清が本 法においては70,000倍稀釈が適当であつた。

男子の血漿を用いて検討した本法の精度は Table 3 のでとく良好であつた。 なお precision は within assay variance $16.9 \%(n=33)$, between assay variance $23.6 \%(n=13)$, water blank は $0.66 \pm 1.58 \mathrm{pg} /$ sample で満足すべきものであつた，本法と Chromato 法の相関関係は No Chromato 法におけるそれと 同様な方法で検討したが，Ghromato 法(X)による測定值は 79.1 $27.0 \mathrm{ng} / \mathrm{ml}$, Direct 法(y)によるそれは 80.2

Table 3. Accuracy of the direct method

\begin{tabular}{|c|c|c|c|c|c|c|}
\hline \multirow[b]{2}{*}{ sample } & \multirow{2}{*}{$\begin{array}{l}\text { steroid } \\
\text { added } \\
\text { (pg) }\end{array}$} & \multicolumn{4}{|c|}{ steroid quantified } & \multirow[b]{2}{*}{ regression equation } \\
\hline & & $\begin{array}{c}\text { mean } \\
(\mathrm{pg})\end{array}$ & $\begin{array}{l}\text { standard } \\
\text { deviation }\end{array}$ & $\begin{array}{l}\text { standard } \\
\text { esror }\end{array}$ & $\begin{array}{c}\text { coefficient } \\
\text { of variation } \\
(\%)\end{array}$ & \\
\hline \multirow{5}{*}{$\begin{array}{c}\text { male } \\
\text { plasma } \\
0.001 \mathrm{ml}\end{array}$} & 0 & 114 & 10.6 & 5.31 & 10.8 & \multirow{5}{*}{$\mathrm{Y}=1.07 \mathrm{X}+111$} \\
\hline & 20 & 130 & 8.95 & 4.47 & 14.5 & \\
\hline & 50 & 167 & 9.94 & 4.97 & 16.8 & \\
\hline & 100 & 214 & 12.6 & 6.30 & 17.0 & \\
\hline & 200 & 329 & 13.7 & 6.85 & 24.0 & \\
\hline
\end{tabular}

Number of determination : 4

$\mathrm{X}=$ steroid adced $\mathrm{Y}=$ steroid quantified

Fig. 5. Comparison of plasma cortisol values between Chromatographic and Direct method.

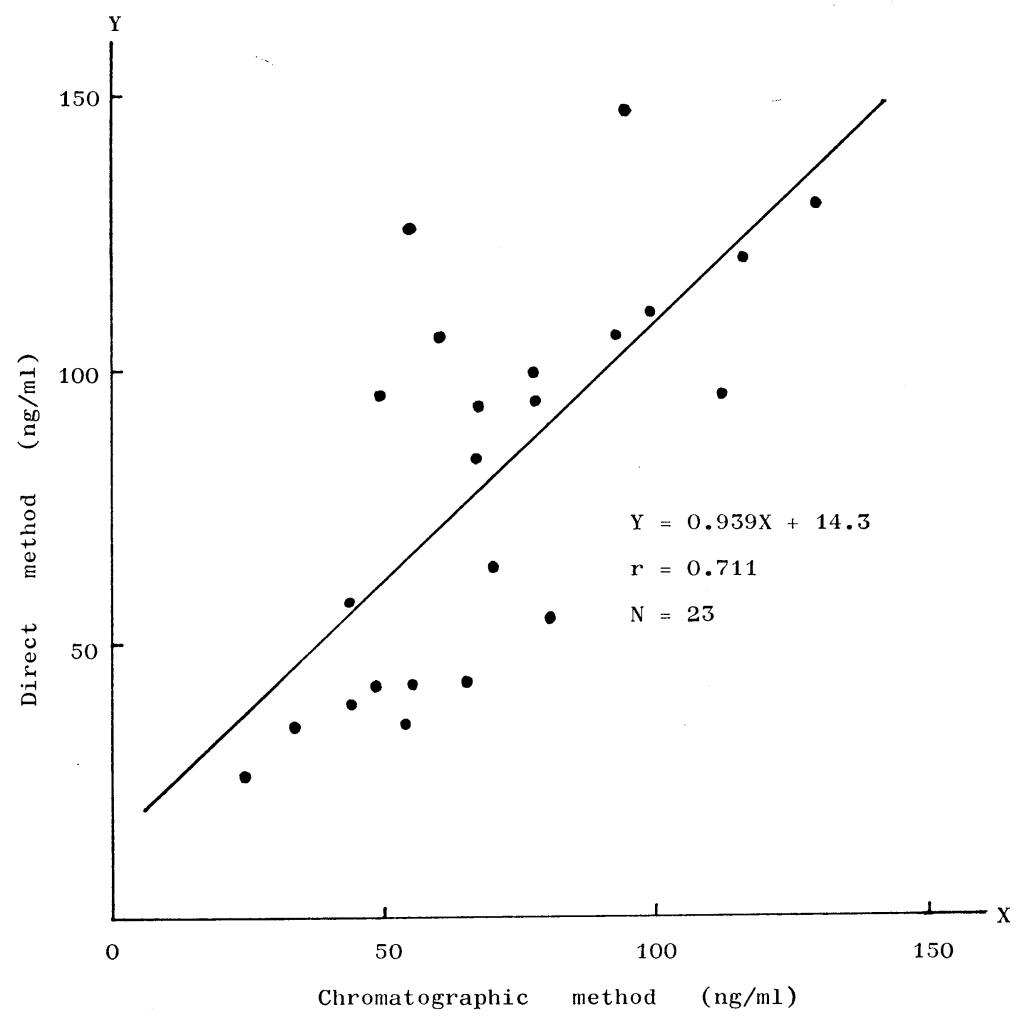

第 49 巻 第 10 号 
土35.8ng/ml で両者間には Fig. 5 に示すでとく良好な相関関係が認められた. また，y と $\mathrm{x}$ 差の $\mathrm{x}$ 亿対 する割合は16.2 土41.6\%であり，乙れの平均值の $95 \%$ 信頼限界における範囲は 34.2 - $1.75 \%$ であつた。 ま た，対応する 2 群の平均值の比較では $\mathrm{y}$ と $\mathrm{x}$ 有意の差は認められなかつた $(\mathrm{p}<0.05)$.

\section{VI 考察}

cortisol の RIA は cortisol-21-hemisuccinate-BSA を抗原として抗血清を作製し，測定する方法か溉に 報告されているが899)，乙の抗原は cortisol の21位の水酸基を BSA 結合部位として用いるためにての部位 の特性が失なわれ，乙れによる抗血清は cortisol 以外の $\mathrm{C}_{21}$ ステロイドにもある程度の affinity を示し， Ruder $ら^{9)}$ は 11-desoxycortisol, 21-desoxycortisol が cortisol と同程度の cross reactivity を示したと報 告しており，われわれの作製した抗血清も 17 $\alpha$-hydroxyprogesterone が高い交叉反応を示している.しか し CBG においては cortisol にほぼ匹敵する affinity を corticosterone, 11-desoxycortisol, 17 $\alpha$-hydroxyprogesterone, progesterone, 21-desoxycortisol などが示し, それ以外の corticoid も cortisol と transcortin の結合部位に競合するととが報告されている ${ }^{1011)}$. したがつて GBG は抗 cortisol 血清よりも cortisol に 対する特異性が低いといえる。

一方，本抗血清は既述のでとく cortisol に対して $\mathrm{K}=1.06 \times 10^{9} l / \mathrm{mole}$ と高い binding affinity を示し ており Ruder らのそれは $2 \times 10^{9} l /$ mole と報告されている。これに対して CBG においては human ${ }^{12)}$ が $5.2 \times 10^{8}\left(4^{\circ} \mathrm{C}\right)$ と $2.4 \times 10^{7}\left(37^{\circ} \mathrm{C}\right)$, rabbit $\left.^{13}\right)$ が $9.0 \times 10^{8}\left(4^{\circ} \mathrm{C}\right)$ と $4.7 \times 10^{7}\left(37^{\circ} \mathrm{C}\right)$ といわれ, cortisol 抗体は CBG に比較して約10〜100倍のKを有する.

標準曲線においても useful range がわれわれの方法で 20〜 500pg と約25倍を有するのに対して CBG assay では通常 2 2ng と約 4 倍にすぎない.

以上のことからこれら抗血清は CBG に比較するとcortisol に対する特異性と親和性, 感度, 測定範囲な どの点で優れており，cortisol assay の結合蛋白としては前進したものといえよう.

本抗血清を用いて血中 cortisol を測定する際にはクロマトによりとのものを分離・精製して assay を行 なうのが理想的ではあるが，可能なかぎり測定法を簡易化するてとはその測定の臨床的応用を応く可能にす るための必要条件の一つである. そのため, 特異性の高い抗血清を用いるととによりクロマトを省略して血 中ステロイドを測定する方法が estradiol-17 $\beta^{\left.14)_{15) 16}\right)}$, estriol ${ }^{14)}$, progesterone ${ }^{\left.\left.14)_{17}\right)_{18}{ }_{199}\right)}$ について検討されて 良好な成績が得られており，さらにWu ら ${ }^{20)} に よ り$ 被検血漿にメタノールを加えて蛋白を沈でんさせ，そ の上清について直接 RIA を行う方法も報告されている.

われわれの作製した抗血清も比較的 cortisol に対する特異性を有しているとと，感度が優れているとと， cortisol はその血中濃度がきわめて高く被検血漿量が少量で良いととなどの理由により， クロマトによる血 中 cortisol の分離・精製を省略した No Chromato 法, さらには吉見らによつて報告された，血漿中の CBG をメタノールを加えて失活させ，乙れに直接，抗血清を加えて RIA を行なう Direct 法の可能性が 考えられた. したがつて正常男子および女子の血漿を用いててれらの方法について検討した結果では Chromato 法に比較していずれも測定值はやや高值を示す傾向が認められるものの臨床応用における簡易法とし ての有用性が示唆された. 特に Direct 法は血漿からの有機溶媒抽出を省略できるとと, 回収率を補正する 必要がないてとなど簡易測定法としては好適であるといえよう。

しかし Table 4 に示すでとく, 前立腺癌患者に chlormadinone acetate (6-chloro-6-dehydro-17 $\alpha$-acetoxyprogesterone）を連日 $100 \mathrm{mg} 3$ ケ月間経口投与した際の簡易法により求めた投与間中の血中 cortisol 值は Chromato 法により求めたそれに比較して明らかに高值を示した. Chlormadinone acetate そのものは抗 cortisol 血清と交叉反応を示さないが，ての薬物は本抗血清に強い交叉反応を示す $17 \alpha$-hydroxyprogesterone の誘導体であるととを考えると, その血中代謝物のなかに抗血清と親和性を有するものが存在し, それに起 因すると考えられる，てのことは，ある種の薬物を投与した際にはそのもの，またはその代謝物の cortisol 值に及ぼす影響を考慮に入れる必要のあるととを示唆しており， corticoid 製剤投与時，さらには下垂体一副 
Table 4. Comparison of plasma cortisol values among three determination methods during administration of Chlormadinone acetate $(100 \mathrm{mg} /$ day) for three months

\begin{tabular}{|c|c|c|c|c|}
\hline \multirow{2}{*}{ name (age) } & \multirow{2}{*}{ No. } & \multicolumn{3}{|c|}{ method } \\
\hline & & Chromato & No Chromato & Direct \\
\hline A.H. (62) & 3 & $74.7 \pm 23.0$ & $104 \pm 15.9$ & $115 \pm 18.7$ \\
\hline T.N. (77) & 4 & $62.9 \pm 23.9$ & $98.2 \pm 40.5$ & $109 \pm 53.3$ \\
\hline S.O. (73) & 3 & $8.16 \pm 5.75$ & $32.5 \pm 26.8$ & $36.4 \pm 49.5$ \\
\hline Y.K. (54) & 2 & $49.4 \pm 14.9$ & $110 \pm 19.7$ & $98.6 \pm 16.1$ \\
\hline \multicolumn{2}{|l|}{ total } & $49.9 \pm 31.4$ & $85.4 \pm 41.1$ & $91.0 \pm 49.2$ \\
\hline
\end{tabular}

$\mathrm{ng} / \mathrm{ml}$ (mean \pm S.D.)

Chlormadinone acetate : 6-chloro-6-dehydro-17 $\alpha$-acetoxyprogesterone

腎皮質系疾患，抑制試験時などにわいて本抗血清による cortisol の測定を行なう際にはクロマトによる純 化が要求されるであろう.

簡易法におけるこれら問題点を解決するためにも今後はより特異性の高い抗血清の作製が望まれ，特に cortisol の構造活性部位である A環の $\Delta^{4}-3$-keto と 11 $\beta ， 17 \alpha ， 21$ 位の水酸基を intact な状態におく杭原の 合成およびその抗血清の作製が期待される.

稿を終るにあたり，御校閲を睗わつた帝国欌器製薬薬理研究部長鈴木竜太博士に感謝致します。また，適 切な御示唆を賜わつた日大産婦人科高木繁夫教授, 吉田孝雄講師ならびに京大第二内科吉見輝也博士に感謝 致します。

また, chlormadinone acetate 投与患者の血浆を御提供頂いた群馬大学泌尿器科志田圭三教授, 島崎淳助 教授に感謝致します。

\section{文 献}

1) Murphy, B.E.P., W. Engelberg and C.J. Pattee : J. Clin. Endocr., $23: 293$, (1963). Abraham, G.E. : J. Clin. Endocr., 29 : 866, (1969).

3）牧野拓雄：日内分泌誌， $49: 629$, (1973). 4) Erlanger, B.F., F. Borek, S.M, Beiser and S. Lieberman : J. Biol. Chem., $228: 713$, (1957). 5) Erlanger, B.F., F. Borek, S.M. Beiser and S. Lieberman : J. Biol. Chem., $234:$ 1090, (1959). Abraham, G.E. and W.D. Odell : Immunologic methods in steroid determination, ed. by Peron, F.G. and Caldwell, B.V., Appleton-Gentury-Crofts, p. 87 (1970). Raskin and A. Heudriks : Acta Endocrin., 33 : 297, (1960). 7) DeMoor, P., O. Steeno, M. 第48回日内分泌学会総会 (1973). 8）吉見輝也，遠藤治郎，立花清司 : ocrinol. Metab., 35 : 219, (1972). 9) Ruder, H.J., R.L. Guy and M.B. Lipsett : J. Clin. EndPincus, G., et al., Academic Press, p. 1 (1966).

10) Sandber, A.A., H. Rosenthal : Steroid Dynamics, ed. by mics, ed. by Pincus, G., et al., Academic Press, p. 63 (1966).

11) Seal, V.S. and R.P. Doe : Steroid DynaWestphal : J. Biol. Chem., $242: 5636$, (1967). Chem., $243: 928,1968 . \quad 14)$ 牧野拓雄 : 投稿中. 13) Chader, G.J. and U. Westphal : J. Biol. P.D.G. Dean : Steroids, 18 : 605, (1971).

16) Gameron, E.H.D. and D.A. Jones : Steroids, 20 : 737, (1972). 17 ) Spieler, J.M., R.L. Webb, R.J. Saldarini and J.A. Coppola : Steroids, 19 : 751, (1972). 18) deVilla, G.O., K. Roberts, W.G. Wiest, G. Mikhail and G. Flickinger : J. Clin. Endocrinol. Metab., 35 : 458, (1972). Castro : Steroids, $20: 697$, (1972). 19) Kutas, M., A. Chung, D. Bartos and A. Gynecol., 115 : 169, (1973). 20) Wu, C.H., L.E. Lundy and S.G. Lee : Am. J. Obstet. 